\title{
PENGARUH STRATEGI KONFLIK KOGNITIF BERBANTUAN \\ MEDIA SEJARAH SAINS TERHADAP SIKAP ILMIAH DAN \\ PERUBAHAN KONSEPTUAL PADA MATERI GERAK
}

\author{
Ardiansyah \\ ardiansyah@iainpalu.ac.id \\ Program Studi Tadris Ilmu Pengetahuan Alam IAIN Palu
}

\begin{abstract}
This research is quantitative and qualitative research. The purpose of this study was to look at the effect of cognitive conflict learning strategies assisted by the history of science media on scientific attitudes and students' conceptual changes in motion material. The research design used was quasi-experimental. The sample of this study was class $X_{B}$ and $X_{C}$ consisting of 66 students, 33 students in the experimental class and 33 students in the control class. The data in this study were taken using: questionnaires, concept understanding tests and interviews. The questionnaire was used to retrieve scientific attitude data, concept understanding tests to retrieve data on students' conceptual changes, and interviews as a complement and supporter of conceptual change data. Data were analyzed using the t-test statistic at 5\% significance level and the $N$-Gain test. The results showed that using SPSS 20 application was obtained for scientific attitude $t_{\text {count }}>t_{\text {table }}(4,637>2,042$ or sig.2-tailed $(0,000)<(0,05)$ and $t_{\text {count }}>t_{\text {table }}(6,974>2,024)$ sig.2tailed $(0,000)<(0.05)$ for conceptual change, which means the hypothesis $\left(H_{0}\right)$ is rejected and $\left(H_{1}\right)$ is accepted and $\langle g\rangle$ obtained in the experimental class is higher than the control class.The conclusion of this study is the cognitive conflict learning strategy assisted by historical media science significantly increases scientific attitude, conceptual change in class $X$ high school students on motion material.
\end{abstract}

Keywords: Learning Strategies for Cognitive Conflicts, Media History of Science, Scientific Attitudes, Conceptual Change.

Abstrak

Penelitian ini merupakan penelitian kuantitatif dan kualitatif. Tujuan penelitian ini untuk melihat pengaruh strategi pembelajaran konflik kognitif berbantuan media sejarah sains terhadap sikap ilmiah dan perubahan konseptual siswa pada materi gerak. Rancangan penelitian yang digunakan adalah quasi eksperimen . sampel penelitian ini adalah kelas $\mathrm{X}_{\mathrm{B}}$ dan $\mathrm{X}_{\mathrm{C}}$ yang 
terdiri atas 66 sisiwa, 33 siswa pada kelas eksperimen dan 33 siswa pada kelas kontrol. Data pada penelitian ini diambil dengan menggunakan: angket, tes pemahaman konsep dan wawancara. Angket digunakan untuk mengambil data sikap ilmiah, tes pemahaman konsep untuk mengambil data perubahan konseptual siswa, dan wawancara sebagai pelengkap dan pendukung data perubahan konseptual. Data di analisisn dengan statistik uji-t pada taraf signifikan $5 \%$ dan uji $\mathrm{N}$-Gain. Hasil penelitian menunjukkan dengan menggunakan aplikasi SPSS 20 diperoleh untuk sikap ilmiah $t_{\text {hitung }}>t_{\text {tabel }}(4,637>2,042$ atau sig.2-tailed $(0,000)<(0,05)$ dan $t_{\text {hitung }}>t_{\text {tabel }}(6.974>2.024)$ sig. 2 -tailed $(0,000)<(0,05)$ untuk perubahan konseptual, yang berarti hipotesis $\left(\mathrm{H}_{0}\right)$ ditolak dan $\left(\mathrm{H}_{1}\right)$ diterima dan $<\mathrm{g}>$ yang diperoleh pada kelas eksperimen lebih tinggi dari kelas kontrol. Kesimpulan dari penelitian ini adalah stategi pembelajaran konflik kognitif berbantuan media sejarah sains berpengaruh secara nyata meningkatkan sikap ilmiah, perubahan konseptual siswa kelas X SMA pada materi gerak.

Kata Kunci: Strategi Konflik Kognitif, Media Sejarah Sains, Sikap Ilmiah dan Perubahan Konseptual.

\title{
Pendahuluan
}

Fisika merupakan suatu mata pelajaran yang menjadi pusat perhatian banyak siswa, baik perhatian pada simbol-simbol matematika, maupun perhatian pada pemahaman mereka tentang fenomena alam sekitar. Salah satu fenomena yang tampak dan natural bagi siswa adalah gerak.

Fenomena gerak sering dijumpai dalam kehidupan sehari-hari siswa, tidak jarang fenomena-fenomena gerak yang dialamti oleh siswa dibangun menjadi sebuah pengetahuan awal siswa (prakonsep). Teori kontruktivisme menyatakan bahwa pengetahuan dibentuk oleh siswa sendiri dengan lingkungan, tantangan dan bahan yang dipelajari (Suparno,1997) ${ }^{1}$. Meskipun siswa belum diajar tentang gerak secara formal di sekolah, akan tetapi siswa telah mengamati kejadian-kejadian tentang gerak di lingkungan sekitarnya yang kemudian di konstruksi oleh siswa menjadi suatu prakonsep. Permasalahan yang sering dialami oleh kebanyakan siswa dalam mengkonstruksi suatu pengetahuan ialah terjadi miskonsepsi dan common sense alternative pada materi gerak, sebab

\author{
Kanisius.1997.
}

${ }^{1}$ Suparno, P. Filsafat Konstruktivisme dalam Pendidikan. Yogyakarta: 
pengetahuan yang dibangun siswa merupakan persepsi mereka tentang alam dan bukan berdasarkan konsepsi ilmiah. Siswa merekonstruksi pengetahuan mereka berdasarkan pengalaman ${ }^{2}$. Oleh sebab itu perlu ada usaha mengubah miskonsepsi dan common sense alternative yang dialami oleh para siswa. Sebuah studi kasus yang dilakukan oleh Henke ${ }^{3}$, Ia mengemukakan bahwa dalam kasus gerak benda para siswa cenderung mengikuti skema "dinamika Aristoteles".

Perubahan konsep siswa yang baik apabila terjadi proses asimilasi dan akomodasi. Dalam asimilasi, siswa diharapkan menggunakan konsepkonsep yang telah ada untuk menghadapi gejala baru dengan suatu perubahan kecil yang berupa penyesuaian, sedangkan dalam akomodasi siswa diharapkan mampu mengganti atau menguban konsep yang lama dengan konsep yang baru ${ }^{4}$. Perubahan konsep secara akomodasi sangat diharapkan ketika seseorang mengalami salah konsep secara keseluruhan, yaitu secara drastis mengalami perubahan konsep. Jika salah konsep yang dimiliki siswa hanya sebagian konsep, maka diperlukan perubahan konsep secara asimilasi. Perubahan konsep asimilasi dan akomodasi inilah yang dimaksud peneliti sebagai pembenahan. Pembenahan dapat diartikan sebagai mengubah dari konsep yang salah menuju konsep yang benar.

Penelitian Setyowati ${ }^{5}$ menemukan bahwa strategi mengajar dengan konflik kognitif ini sangat efektif digunakan guru untuk memotivasi belajar siswa dan memfokuskan perhatian siswa pada pembelajaran, dengan demikian konflik kognitif sangat bagus untuk digunakan pada kegiatan awal pembelajaran. Strategi ini dapat membantu siswa membentuk ide baru berdasarkan pengetahuan dan pengalaman terdahulu, memberi kesempatan kepada siswa untuk berfikir dan mengubah miskonsepsi siswa, dan menantang siswa untuk berfikir dan memberikan rasa puas pada siswa ketika prediksi siswa sesuai dengan pengamatan.

\footnotetext{
${ }^{2}$ Suparno, P. Miskonsepsi dan Perubahan Konsep dalam Pendidikan Fisika, (Jakarta: Grasindo. 2014), 22.

${ }^{3}$ Henke, A. Case Studies for Teaching and Learning With History and Phlosophy of Sciences. Paper presented at the Tenth International History, Phylosophy, and Science Teaching Conference University of Notre Dame. 2009.

${ }^{4}$ Jeanne E. Ormrod, Psikologi Pendidikan Edisi ke Enam, (Jakarta: Erlangga. 2008) 86

${ }^{5}$ Setyowati, Subali, dan Mosik. "Implementasi Pendekatan Konflik Kognitif dalam Pembelajaran Fisika untuk Menumbuhkan Kemampuan Berpikir Kritis Siswa SMP Kelas VIII”. JPFI.7(1) 2011, 89-96.
} 
Sutisna ${ }^{6}$ mengemukakan bahwa pada kondisi konflik kognitif, siswa dihadapkan pada tiga pilihan yaitu: (1) mempertahankan intuisinya semula, (2) merevisi sebagian intuisinya melalui proses asimilasi, (3) mengubah pandangannya yang bersifat intuisi tersebut dan mengakomodasikan pengetahuan baru. Jika siswa memilih pilihan ketiga maka akan terjadi perubahan konsep pada diri siswa. Konflik kognititf yang disajikan guru, diharapkan dapat menyadarkan siswa atas kekeliruan konsepsinya dan pada akhirnya mereka merekonstruksi konsepsinya menuju konsepsi ilmiah. Menciptakan konflik kognitif merupakan fase yang penting dalam pembelajaran, sebab dengan adanya konflik tersebut siswa merasa tertantang untuk belajar apalagi jika peristiwa yang dihadirkan tidak sesuai dengan pemahamannya.

Baser $^{7}$ mengemukakan pembelajaran konflik kognitif dapat mendorong adanya perubahan konsep siswa pada arah yang positif. Perubahan konsep siswa pada arah yang positif bermuara pada penguasaan konsep yang baik. Pembelajaran konflik kognitif memiliki keunggulan antara lain dapat mendorong perubahan konsep siswa dari konsep yang salah menjadi konsep yang benar, serta dapat menciptakan situasi pembelajaran yang dinamis melalui beragam metode pembelajaran. Dalam penggunaan metode pembelajaran yang tepat sebaiknya media yang digunakan juga harus tepat dalam mengatasi perubahan konsep siswa, sebuah laporan proyek interaktif kualifikasi oleh Fagan $^{8}$ mengemukakan bahwa penggunaan media sejara dalam pengajaran fisika dapat mendorong siswa untuk berfikir lebih luas tentang materi yang disajikan dengan dunia mereka. Dari hasil survey, sebagian siswa telah memperoleh pengetahuan dasar tentang materi fisika.

Banyak penelitian telah dilakukan untuk mengungkap pemahaman siswa tentang konsep-konsep gerak. Beberapa penelitian menunjukkan banyak siswa dan mahasiswa yang mempunyai konsepsi salah terkait dengan materi gerak ${ }^{9}$. Penelitian yang dilakukan oleh Akbar

${ }^{6}$ Sutisna, A. Pengembangan Model Pembelajaran Konflik Kognitif untuk Memfasilitasi Perubahan Konseptual dan Peningkatan Keterampilan Berpikir Kritis Siswa pada Materi Termokimia. Tesis Magister pada Pasca Sarjana Universitas Pendidikan Indonesia Bandung: tidak diterbitkan.2013

${ }^{7}$ Baser, M. Fostering Conceptual Change by Cognitive Conflict Based Instruction on Student Understanding of Heat and Temperature Concepts. Eurasia Journal of Mathematics, Science and Technology Education. 2(2)2006,96-114.

${ }^{8}$ Fagan, M. Teaching the History of Sciences: An Experiment in the perseption of historical education. An interactive qualifying project report submitted to the faculty of Worcester Polytechnic University, Pamona. 2012. Hal. 9

${ }^{9}$ Suparno, Miskonsepsi..., 13. 
mengungkapkan bahwa pembelajaran dengan menggunakan media sejarah sains (mss) mampu mempengaruhi konsep siswa dari pandangan yang mendukung ide-ide Aristoles (Aristotelian) kepada pandangan yang mendukung ide-ide Newton (Newtonian). Namun, sejauh ini di Indonesia masih sedikit penelitian yang mengungkap konsepsi dan perubahan konsep siswa terkait dengan pengalaman belajar siswa di kelas ${ }^{10}$.

Terkait penelitian yang dilakukan oleh Susilawati ${ }^{11}$ mengungkapkan dalam peningkatan pemahaman konseptual siswa menunjukkan bahwa keterkaitan penguasaan konsep siswa dengan sikap ilmiah siswa itu sendiri, dari hasil penelitiannya menunjukkan bahwa kelompok siswa yang memiliki sikap ilmiah yang tinggi memperoleh nilai rata-rata pemahaman konsep yang tinggi juga, hal ini didukung oleh penelitian yang dilakukan oleh Widiadnyana ${ }^{12}$, menyatakan terdapat perbedaan nilai rata-rata pemahaman konsep siswa yang memiliki sikap ilmiah yang tinggi dengan sikap ilmiah yang rendah.

Berdasarkan latar belakang diatas maka dipandang perlu penulis mengkaji perubahan konseptual berbantuan media sejarah sainsdan sikap ilmiah pada materi gerak melalui starategi konflik kognitif. Dari uraian diatas mendorong peneliti untuk meneliti dengan judul "Pengaruh Strategi Pembelajaran Konflik Kognitif Berbantuan Sejarah Sains terhadap Sikap Ilmiah dan Perubahan Konseptual Siswa kelas X SMAN pada materi Gerak.

\section{Metode Penelitian}

Jenis penelitian ini yaitu penelitian yang bersifat kuantitatif dengan rancangan quasi experiment dengan menggunakan satu kelas eksperimen yang menggunakan strategi konflik kognitif berbantuan media sejarah sains. Namun, aspek-aspek yang berkaitan dengan perubahan konsep dan sikap ilmiah dianalisis menggunakan pendekatan kualitatif.

${ }^{10}$ Ilham Akbar, "Pengaruh Media Sejarah Sains Terhadap Perubahan Konseptual siswa pada materi gerakan dan gaya". Tesis, tidak diterbitkan. Palu: Program Pascasarjana Universitas Tadulako. 2014.

${ }^{11}$ Susilawati, K., Budi, P.A., Bagus, Ida. J. Pengaruh Model Siklus Belajar 7E Terhadap Pemahaman Konsep Biologi dan Sikap Ilmiah Siswa. e-Jurnal Program Pascasarjana Universitas Pendidikan Ganesha program pendidikan IPA. 4(1) 2014. 111

${ }^{12}$ Widiadnyana, I W., Sadia, I W., Suastra, I W. Pengaruh Discovery Learning terhadap Pemahaman Konsep dan Sokap Ilmiah Siswa SMP. e-Jurnal Program Pascasarjana Universitas Pendidikan Ganesha program pendidikan IPA. Vol. 4(1) 2014. 1-13 
Bentuk desain penelaitian ini adalah Nonrandomized control group pretest-posttest design. Dimana desain ini terdapat dua kelompok, yaitu kelompok eksperimen dan kelompok kontrol

Penelitian ini dilaksanakan di SMA Negeri 1 Sojol pada kelas X. Pengambilan sampel dalam penelitian ini menggunakan teknik simple random sampling yaitu mengambilan dua kelas secara acak dari seluruh kelas yang ada. Kelas XA sebagai kelas eksperimen dan XC sebagai kelas kontrol.

Jenis data yang akan dikumpulkan dalam penelitian ini adalah data kuantitatif dan data kualitatif. Data kuantitatif berupa tes awal dan teas akhir berupa tes pemahaman konsep. Data kualitatif berupa angket sikap ilmiah dan wawancara.Penarikan kesimpulan berdasarkan uji Hipotesis Uji-t dan Uji N-Gain.

\section{Pembahasan}

Pengujian Persyaratan Analisis

Pengujian prasyarat analisis menggunakan uji normalitas dan homogenitas menggunakan aplikasi SPSS 20 diperoleh uji normalitas dengan menggunakan uji Kolmogrov-Smirnov diperoleh data perubahan konsep dan sikap ilmiah pada kelas kontrol dan eksperimen terdistribusi normal, untuk uji homogenitas menggunakan uji Homogenity Test diperoleh nilai tes perubahan konsep dan sikap ilmiah pada kelas eksperimen sehingga dapat disimpulkan bahwa keempat sampel databerasal dari populasi yang sama.

\section{Uji N-Gain Sikap Ilmiah}

Uji N gain yang dilakukan pada Sikap Ilmiah siswa diperoleh untuk kelas eksperimen sebesar N-gain 50\% dalam kategori Sedang. Sedangkan pada kelas kontrol nilai N-gainnya sebesar 38,1\% dalam kategori Sedang. Perbandingan dimensi kelas eksperimen dan kontrol bisa dilihat pada tabel 1 dan 2.

\section{Tabel 1}

Dimensi sikap ilmiah pada kelas eksperimen

\begin{tabular}{llcccc}
\hline No & $\begin{array}{c}\text { Kompotensi Sikap } \\
\text { Ilmiah }\end{array}$ & Posttest & Pretest & $\begin{array}{c}\text { N-Gain } \\
(\mathbf{\%})\end{array}$ & Keterangan \\
\hline 1 & Sikap Jujur & 84 & 48 & 42,857 & Sedang \\
\hline 2 & Sikap Ingin Tahu & 173 & 104 & 43,125 & Sedang \\
\hline 3 & Sikap Kritis & 361 & 263 & 36,981 & Sedang \\
\hline 4 & Sikap Tekun & 211 & 129 & 60,741 & Sedang \\
\hline 5 & Sikap Bekerja sama & 624 & 430 & 53,591 & Sedang \\
\hline 6 & Sikap Sosial & 217 & 133 & 64,122 & Sedang \\
\hline
\end{tabular}


Tabel 2

Dimensi sikap ilmiah pada kelas Kontrol

\begin{tabular}{clcccc}
\hline No & $\begin{array}{c}\text { Kompotensi Sikap } \\
\text { Ilmiah }\end{array}$ & Posttest & Pretest & $\begin{array}{c}\text { N-Gain } \\
(\%)\end{array}$ & Keterangan \\
\hline 1 & Sikap Jujur & 79 & 66 & 19,7 & Rendah \\
\hline 2 & Sikap Ingin Tahu & 159 & 120 & 27,08 & Rendah \\
\hline 3 & Sikap Kritis & 352 & 271 & 31,52 & Sedang \\
\hline 4 & Sikap Tekun & 194 & 137 & 44,88 & Sedang \\
\hline 5 & Sikap Bekerja sama & 579 & 440 & 39,49 & Sedang \\
\hline 6 & Sikap Sosial & 214 & 132 & 62,12 & Sedang \\
\hline
\end{tabular}

Uji N-Gain tes perubahan konsep

Penelitian ini bertujuan untuk melihat dan mengetahui bagaimana pengaruh dari pembelajaran strategi konflik kognitif berbantuan sejarah sains terhadap perubahan konsep tentang gerak. Uji N-Gain yang dilakukan pada tes perubahan konsep diperoleh terdapat perbedaan hasil preetest dan posttest pada kelas eksperimen tersebut. dimana besar NGain adalah 65,23\% dalam kategori sedang, sedangkan Kelas Kontrol nilai N-gain yang diperoleh sebesar $51,77 \%$ dalam kategori peningkatan Sedang. Perbedaan rerata untuk tiap butir soal pada kelas kontrol bisa dilihat pada tabel 3 dan 4 dan Digram 1 dibawah ini.

Tabel.3

Rerata Skor Butir soal Kelas Eksperimen

\begin{tabular}{clcccc}
\hline $\begin{array}{c}\text { No } \\
\text { Soal }\end{array}$ & \multicolumn{1}{c}{ Konsep } & \multicolumn{2}{c}{ Skor } & Gain & \multirow{2}{*}{ Kriteria } \\
\hline 1 & Gerak relatif & 3,13 & 0,5 & 75,1 & Tinggi \\
\hline 2 & Jarak dan perpindahan & 5,41 & 1,04 & 73,3 & Tinggi \\
\hline 3 & GLB & 2,65 & 0,59 & 46,7 & Sedang \\
\hline 4 & GLBB & 2,00 & 0,06 & 49,2 & Sedang \\
\hline 5 & GJB & 3,85 & 0,09 & 76,6 & Tinggi \\
\hline
\end{tabular}

Tabel.4

Rerata Skor Butir soal Kelas Kontrol

\begin{tabular}{clcccc}
\hline $\begin{array}{c}\text { No } \\
\text { Soal }\end{array}$ & \multicolumn{1}{c}{ Konsep } & \multicolumn{2}{c}{ Skor } & Gain & \multirow{2}{*}{ Kriteria } \\
\hline 1 & Gerak relatif & 3,13 & 0,5 & 75,1 & Tinggi \\
\hline 2 & Jarak dan perpindahan & 5,41 & 1,04 & 73,3 & Tinggi \\
\hline 3 & GLB & 2,65 & 0,59 & 46,7 & Sedang \\
\hline 4 & GLBB & 2,00 & 0,06 & 49,2 & Sedang \\
\hline 5 & GJB & 3,85 & 0,09 & 76,6 & Tinggi \\
\hline
\end{tabular}




\section{Uji T Sikap Ilmiah}

Nilai $\mathrm{t}_{0}>\mathrm{t}_{\text {Tabel }}=4.637>2.042($ diperoleh dari table distribusi $\mathrm{t})$ dan baris $\mathrm{Sig}\left(1\right.$-tailed) $0.000<0.05$, dengan demikian disimpulkan bahwa $\mathrm{H}_{0}$ ditolak dan $\mathrm{H}_{1}$ diterima sehingga terdapat pengaruh yang signifikan strategi konflik kognitif berbantuan media sejarah sains terhadap Sikap Ilmiah siswa siswa pada tingkat kepercayaan $95 \%$.

\section{Uji T Perubahan Konsep}

Nilai $t_{0}>t_{\text {Tabel }}=6.974>2.042$ (diperoleh dari table distribusi $\mathrm{t}$ ) dan baris $\mathrm{Sig}\left(1\right.$-tailed) $0.000<0.05$, dengan demikian disimpulkan bahwa $\mathrm{H}_{0}$ ditolak dan $\mathrm{H}_{1}$ diterima sehingga terdapat pengaruh yang signifikan strategi konflik kognitif berbantuan media sejarah sains terhadap perubahan konsep siswa pada tingkat kepercayaan 95\% .

\section{Perubahan Konsep}

Perubahan konsep yang terjadi pada siswa cukup hal ini dapat dilihat dari rata-rata $\mathrm{N}$ gain yang diperoleh yaitu 54,36\% dengan kriteria sedang. Seperti yang telah dikatakan sebelumnya, walaupun semua siswa mengalami perubahan konsep secara baik masih terdapat miskonsepsi pada setiap konsep yang ada. Hal ini disebabkan siswa memiliki konsep awal dan ini sangat bersifat resisten. Hasil ini didukung dengan pernyataan Suparno ${ }^{13}$ bahwa konsep yang bertentangan dengan teori atau konsep awal siswa tidak selalu diterima. Siswa yang tidak menerima, tidak akan menghasilkan perubahan konsep secara kuat, sedangkan bila menerima akan menghasilkan perubahan konsep secara kuat atau akomodasi.

Beragam metode yang digunakan dalam pembelajaran strategi konflik kognitif ini. Namun pada akhirnya, siswa sendirilah yang mengontrol proses-proses kognitif yang memudahkan mereka memahami gagasan-gagasan baru dan mendapatkan pemahaman yang lebih baik. Kecakapan mereka dalam mengarahkan usaha belajar dan pemahamam mereka sendiri mengenai apa artinya mempelajari sesuatu merupakan unsur-unsur kunci dalam proses merevisi pemikiran mereka tentang materi tertentu di kelas (Ormord, 2008) ${ }^{14}$.

Uji hipotesis dengan menggunakan uji $\mathrm{t}$ diperoleh nilai $\mathrm{t}_{0}>\mathrm{t}_{\text {hitung }}=$ $6.974>2.042$ (diperoleh dari table distribusi t) dan baris Sig(1-tailed) $0.000<0.05$, dengan demikian disimpulkan bahwa $\mathrm{H}_{0}$ ditolak dan $\mathrm{H}_{1}$ diterima sehingga terdapat pengaruh yang signifikan strategi konflik kognitif berbantuan media sejarah sains terhadap perubahan konsep siswa

\footnotetext{
${ }^{13}$ Suparno, Miskonsepsi..., 4

${ }^{14}$ Ormrod, Psikologi..., 72
} 
pada tingkat kepercayaan $95 \%$ dan taraf nyata 0.025 . Peningkatan ini terjadi setelah dilakukan proses belajar mengajar menggunakan strategi konflik kognitif. Hasil penelitian ini sejalan dengan hasil penelitian Meidahrianti ${ }^{15}$ yang menemukan bahwa pembelajaran dengan menggunakan strategi konflik kognitif dapat menimbulkan perubahan konsep pada siswa. Penelitian Nunung juga menunjukkan bahwa pendekatan konflik kognitif dapat mengurangi miskonsepsi siswa pada konsep usaha dan energi dengan tingkat pemahaman rata-rata sebesar $74 \%$.

Perubahan konsep yang dialami oleh siswa terlihat pada konsep Gerak relatif, Jarak dan besaran perpindahan dan GJB siswa sebagian besar sudah mengubah prakonsep yang keliruh ke konsep yang sesungguhnya. Pada konsep GLB dan GLBB masih ada siswa yang belum paham, kesulitan siswa dalam konsep ini yaitu siswa merasa bingung antara kecepatan dan percepatan pada saat kapan suatu benda itu dikatakan mengalami kecepatan dan pada dan kapan benda mengalami percepatan.

Soal Nomor 1 mengenai konsep gerak.

Berdasarkan Tabel 4.6 sampai tabel 4.8, dapat dilihat bahwa pemahaman responden terkait soal No. 1 memberikan gambaran bahwa Responden Resp-01 Resp-21 dan Resp-11 mula-mula belum memahami tentang konsep gerak relatif. Menurut Responden teman yang sedang berdiri dipinggir jalan itu dikatakan tidak bergerak (Diam) yang bergerak adalah mobil. Jawaban ini belum benar, selain itu responden belum dapat mengidentifikasi dan mengkoneksikan kasus pada soal No. 1 dengan konsep gerak. Setelah dilakukan proses belajar mengajar dengan menggunakan strategi konflik kognitif berbantuan media sejarah sains Responden Resp-01 memberikan jawaban yang menarik kepada peneliti, Resp-01 mengatakan orang dipinggir jalan dikatakan bergerak kalau titik acuannya adalah pusat bumi karena bumi ini mengalami rotasi atau perputaran hanya saja tidak dirasakan oleh manusia, jawaban responden ini sudah benar akan tetapi responden belum bisa menghubungkan dengan konteks soal kaitannya antara orang yang berdiri diam dipinggir jalan dengan mobil yang bergerak. Responden Resp-01 sudah mulai memahami tentang konsep gerak relatif. Menurut Responden Resp-01, untuk menentukan suatu benda dikatakan bergerak harus ditentukan dulu titik acuannya dimana. Untuk responden Resp-21

${ }^{15}$ Meidahrianti, Zulherman dan Taufiq, "Pengaruh Strategi Pembelajaran Konflik Kognitif terhadap Perubahan Konseptual Siswa pada Materi Gerak dinamis SMAN 1 Tanjung Batu”. Jurnal inovasi pembelajaran fisika. 1(1) 2014. 48-55 
dan Resp-11setelah diberi pengajaran strategi konflik kognitf berbantuan media sejarah sains sudah menjawab dengan benar, walaupun dari segi jawaban yang ditulis belum sempurna, akan tetapi di sesi wawancara peneliti berusaha melihat sejauh mana perubahan konsep soal nomor 1dan ditemui bahwa Resp-21 dan Resp-11 sudah memahami konsepnya kapan benda dikatakan bergerak kapan benda diakatakan diam.

Pertanyaan soal No. 1 jawaban yang benar seharusnya teman yang berdiri dipinggar jalan bisa dikatakan bergerak jika titik acuannya adalah orang yang berada didalam mobil atau mobil, dan teman juga dikatakan tidak bergerak jika titik acuannya adalah dirinya sendiri atau pepohonan dipinggir jalan. Gerak merupakan perubahan posisi suatu benda pada saat tertentu terhadap titik acuannya atau gerak bersifat relatif.

Peneliti melakukan pembelajaran strategi konflik kognitif berbantuan media sejarah sains pertama peneliti meminta tagihan bacaan bahan ajar media sejarah sains yang bertujuan agar semua siswa mempunyai prakonsep bisa membentuk prakonsep melalui media sejarah sains selain itu siswa yang sudah memiliki prakonsep bisa mendapatkan pendukung prakonsepnya dari teori-teori penemuan gerak yang dikemukakan oleh Aristoteles, Galileo, Newton dan Keppler.

Selanjutnya mengajukan pertanyaan konflik kognitif ke siswa apakah spidol yang diletakkan di atas lantai dalam keadaan diam dikatakan bergerak jika gifar (salah satu murid) berjalan mendekati spidol? Sebagian besar siswa menjawab tidak. Peneliti kemudian menanyakan kepada beberapa siswa mengapa dia mengatakan tidak bergerak, ada mengatakan bahwa spidol tidak bergerak karena tidak diberi gaya (berfikir Aristotelian), ada juga yang mengatakan bahwa karena tidak ada perubahan posisi (berfikir Aristotelian). Bahkan ada yang mengatakan hukum newton 1 mengatakan bahwa benda yang diam akan selalu diam, berarti spidol diletakkan diatas lantai posisinya diam maka dia akan selalu diam (pola pikir Newtonian-Aristotelian). Untuk mempertentangkan prakonsep siswa peneliti menyampaikan apa yang dimakseud dengan gerak, lalu melanjutkan dengan melakukan demonstrasi sederhana. Peneliti meminta Gifar salah satu siswa berjalan ke depan kelas, lalu menanyakan ke siswa lain apakah gifar dikatakan bergerak, serentak semua siswa menjawab "Bergerak" lalu peneliti menanyakan lagi kenapa kalian katakan bergerak? serentak siswa menjawab karena terjadi perubahan jarak/posisi gifar. Peneliti mengajukan pertanyaan lagi, sekarang lihat posisi awal gifar terhadap spidol, bandingkan dengan posisi gifar terhadap spidol setelah gifar bergerak, apakah terjadi perubahan jarak/kedudukan seperti yang kalian 
sebutkan? serentak siswa menjawab " terjadi perubahan jarak antara gifar dan spidol" peneliti kemudian mengajukan pertanyaan lagi, jadi apakah spidol dikatan bergerak terhadap gifar? Disini siswa ada yang sudah bisa mengubah prakonsepnya dengan mengatakan bahwa spidol dikatakan bergerak, dan sebagian siswa masih mengatakan bahwa spidol tidak bergerak yang bergerak adalah gifar, disini peneliti mulai melakukan proses asimilasi dan akomodasi kepada siswa, siswa di kelompokkan menjadi dua kelompok yang mengatakan diam dan yang mengatakan bergerak, setiap kelompok diminta mengeluarkan argumen mengenai pendapatnya, pada saat siswa yang mengatakan spidol itu tidak bergerak sudah bisa mengubah prakonsepnya peneliti kemudian melakukan penguatan dengan mengatakan benda diam bisa saja dikatakan bergerak atau diam tergantung dari titik acuannya, kalau titik acuannya bergerak maka benda diam itu bisa dikatakn bergerak, dan bila titik acuannya juga diam maka benda dikatakan diam atau tidak bergerak.

Hasil Posttest Responden Resp-21 dan Resp-11 dan sebagian besar siswa sudah mampu menggubah prakonsepnya ke konsep yang benar setelah mendapatkan pengajaran dengan menggunakan stragei konflik kognitif berbantuan media sejarah sains.

Soal Nomor 2 mengenai konsep Jarak dan Perpindahan.

Berdasarkan Tabel 4.9 sampai tabel 4.11 dapat dilihat bahwa pemahaman responden terkait soal No. 2 memberikan gambaran bahwa Responden Resp-01, Resp-21 dan Resp-11 mula-mula belum memahami tentang konsep jaran dan perpindahan. Menurut Resp-01dan Resp-11bahwa jarak dan perpindahan jarak dan perpindahan itu sama, sedangkan Resp-21 mengatakan bahwa jarak dan perpindahan itu sama akan tetapi Resp-21 belum bisa menunjukkan perbedaaan jarak dan perpindahan secara benar, hanya membedakan berdasarkan defenisi dari jarak dan perpindahan. Setelah dilakukan proses belajar mengajar dengan menggunakan strategi konflik kognitif berbantuan media sejarah sains Responden Resp-01 memberikan jawaban yang menarik kepada peneliti, terlihat dari hasil posttest Resp-01 menjawab untuk lintasan I jaraknya sudah benar akan tetapi pada perpindahannya Resp-01 menjawab salah sedangkan Lintasan II dan III Resp-01 sudah menjawab dengan Benar, peneliti menganalisis bahwa Resp-01 belum memahami Perbedaan antara Jarak dan Perpindahan, sehingga peneliti melakukan wawancara kepada Resp-01 untuk mengetahui sejauh mana perubahan konsepnya untuk nomor 2 , beberapa pertanyaan yang ditanyakan kepada Resp-01 salah satunya pneliti menanyakan jarak dan perpindahan itu termaksud dalam besaran Vektor atau skalar? Dari wawancara itu sebenarnya Resp-01 memahami perbedaan antara Jarak dan perpindahan, 
dan setelah Resp-01 diminta mengulangi pengerjaan soal nomor 2 untuk Lintasan I, Resp-01 mampu menjawab dengan benar jarak dan perpindahannya, sehingga peneliti menyimpulkan bahwa Resp-01 sebenarnya mampu menyelesaikan soal nomor 2, hanya saja Resp-01 kurang mampu menginterpretasi bentuk lintasan hal itu diperoleh oleh peneliti karena pada prose Resp-02 diminta untuk mengerjakan kembali soal nomor 2, Resp-01 banyak menanyakan tentang bentuk lintasan menurut Resp-01 masih bingung melihat garis bentuk lintasan, selain itu menurut peneliti kegagalan Resp-01 dalam menyelesaiakan soal nomor 2 dikarenakan Resp masih kurang melatih diri dalam menyelesaiakan soal yang berbentuk gambar, grafik dan garis, pada soal nomor 2 ada tiga bentuk lintasan yang berbeda-beda digambarkan dalam bentuk garis, pada soal lintasan II Resp-01 bisa menjawab dengan benar jarak dan perpindahannya karena bentuk lintasannya adalah garis lurus yang mana peneliti pernah mencontohkan perbedaan antara jarak dan perpindahan pada garis lurus, akan tetapi pada lintasan I bentuk lintasannya bukan berupa garis lurus, sehingga Resp-01 kesulitan untuk menyelesaikan soal tersebu.

Responden Resp-21 dan Resp-11 dapat menyelesaikan soal nomor 2 dengan benar dari hasil wawancara keduanya menunjukkan bahwa responden sudah dapat merubah prakonsep sebelumnya menjadi pengetahuan yang sesungguhnya yang sesuai dengan konsep yang ilmiah, hal itu terlihat dari jawaban hasil wawancara kedua responden sudah mampu membedakan antara jarak dan perpindahan dari ketiga bentuk lintasan, bahkan Resp-11 mampu melukiskan lintasan sebelum menjawab berapa besar jarak dan perpindahannya.

Proses pembelajaran menggunakan strategi pembelajaran berbantuan media sejarah sains peneliti mengajukan sebuah pertanyaan kepada semua siswa untuk mengetahui prakonsep siswa, peneliti menanyakan apakah jarak dan perpindahan itu sama? Sebagian besar siswa menjawab sama, sebagian lagi menjawab tidak sama, selanjutnya peneliti meminta pendapat siswa yang mengatakan jarak dan perpindahan itu sama begitu pun yang mengatakan bahwa jarak dan perpindahan itu tidak sama, sebagian besar siswa yang mengutaran pendapat (prakonsepnya) mengatakan bahwa: "panjang lintasan dari kelas ke kantin yaitu $10 \mathrm{~m}$. misalnya saya berjalan dari kelas ke kantin berarti jarak saya $10 \mathrm{~m}$ perpindahannya juga $10 \mathrm{~m}$ ". sedangkan siswa yang mengatakan jarak dan perpindahan itu tidak sama memberikan pendapatnya (prakonsepnya) dengan menyebutkan bahwa jarak dan perpindahan itu berbeda lalu membaca defenisi dari jarak dan perpindahan. Peneliti melihat adanya perbedaan prakonsep pada siswa akan tetapi belum kuat untuk 
dikonflikkan karena kedua pendapat tersebut belum ada yang menunjukkan ke konsep yang sebenarnya, sehingga peneliti melakukan demonstrasi sederhana dengan meminta 4 orang siswa bendiri pada garis yang lurus setiap siswa menunjukkan satu titik (A-B-C-D) yang akan dilalui oleh Gifar (siswa yang bertindak sebagai objek), jarak antara satu titik ke titik lainya yaitu 1 meter. Kemudian peneliti mengarahkan Gifar berdiri disamping siswa yang sebagai titik A lalu berjalan ketemannya paling ujung di titik $\mathrm{D}$, kemudian peneliti mengajukan pertanyaan ke semua siswa, berapa jarak gifar dari titik A ke titik D? Serentak semua siswa menjawab "3 meter" kemudian peneliti menayakan lagi perpindahannya serentak menjawab "3 meter". Peneliti selanjutnya mengajukan pertanyaan berarti jarak dan perpindahan itu sama atau tidak? Sebagian kecil siswa yang menjawab sama, yang lainnya diam. Hal ini menunjukkan bahwa siswa sebagian besar sudah mengalami konflik dalam dirinya sendiri, yang mana prakonsep yang dianut sudah mulai diragukan, maka proses asimilasi dan akomodasi segerah peneliti munculkan dengan meminta gifar kembali ke titik A, lalu peneliti menanyakan kembali ke siswa berapa jarak gifar sekarang dari titik A ke titik D kemudian kembali ke titik A? Siswa menjawab dengan ragu-ragu" 6 meter" kemudian peneliti memberi penguatan jawaban dari siswa agar siswa lain yang masih ragu-ragu menjadi yakin. Kemudian peneliti mengajukan pertanyaan bagaimana dengan perpindahan Gifar dari titik A ke titik D kemudian kembali ke titik A? Dengan ragu- ragu siswa menjawab Nol. Kemudian peneliti melakukan penjelasan dan penguatan dari jawaban yang disampaikan siswa dengan mengatakan jarak itu besaran skalar yang tidak memperhatikan arah gerak benda sehingga jarak merupakan panjang semua lintasan yang dilalui, sedangkan perpindahan merupakan besaran vektor yang memperhatikan arah gerak benda yang hanya bergantung pada posisi awal dan akhir saja. akhirnya siswa mampu membedakan jarak dan perpindahan.

Responden Resp-21 dan Resp-11 dan sebagian besar siswa sudah mampu menggubah prakonsepnya ke konsep yang benar.

Soal Nomor 3 mengenai konsep GLB.

Berdasarkan Tabel 4.12 sampai tabel 4.14, dapat dilihat bahwa pemahaman responden terkait soal No. 3 memberikan gambaran bahwa Responden Resp-01, Resp-21 dan Resp-11 mula-mula belum memahami tentang konsep GLB. Responden tidak mengetahui apa itu kecepatan, percepatan kecenderungan responden mengartikan kecepatan dan percepatan itu sama. Setelah dilakukan proses belajar mengajar dengan menggunakan strategi konflik kognitif berbantuan media sejarah sains Responden Resp-21 memberikan jawaban yang menarik kepada 
peneliti, Resp-21 mengatakan bahwa spidometer bus yang menunjukkan angka $50 \mathrm{~km} / \mathrm{jam}$ selama 10 menit itu mengalami percepatan tapi percepatannya tetap, setelah di lakukan wawancara oleh peneliti Resp-21 belum begitu paham mengenai kecepatan dan percepatan dia menjawab menjawab soal nomor 3 berdasarkan ingatannya bahwa di GLBB percepatannya tetap. Resp-21 mengira soal nomor 3 merupakan contoh GLBB. Responden Resp-01 dan Resp-11 sudah memahami konsep GLB setelah diberikan pembelajaran dengan menggunakan strategi konflik kognitif berbantuan media sejarah sains.

Soal No. 3 mengenai konsep kelajuan. Selama proses pembelajaran guru memberikan pernyataan yang dapat menimbulkan konflik dalam pikiran siswa, bentuk pernyataan "husen berlari dengan kecepatan $0,5 \mathrm{~m} / \mathrm{s}$ kearah selatan. Dari penyataan ini bisa dikatan bahwa kelajuannya adalah $0,5 \mathrm{~m} / \mathrm{s}$ sedangkan kecepatannya $0,5 \mathrm{~m} / \mathrm{s}$ ke selatan"Guru mencoba menimbulkan konflik dalam pikiran siswa dengan mengajukan pertanyaan "Dari pernyataan di atas apa yang Anda ketahui tentang kelajuan dan kecepatan?". Siswa menjawab kalau kelajuan hanya bergantung pada nilai (Kelajuan pelari $10 \mathrm{~m} / \mathrm{s}$ ) sedangkan kecepatan memiliki nilai dan arah (kelajuan pelari $10 \mathrm{~m} / \mathrm{s}$ kearah selatan). Guru kembali mengajukan pertanyaaan "apa perbedaan antara kelajuan dan kecepatan" Peneliti berfokus mengamati situasi kelas sesaat setelah memberikan pertanyaan.

Responden Resp-01 dan Resp-11 dan sebagian besar siswa sudah mampu menggubah prakonsepnya ke konsep yang benar setelah mendapatkan pengajaran dengan menggunakan stragei konflik kognitif berbantuan media sejarah sains .

Soal Nomor 4 mengenai konsep GLBB.

Berdasarkan Tabel 4.15 sampai tabel 4.17, dapat dilihat bahwa pemahaman responden terkait soal No. 4 memberikan gambaran bahwa Responden Resp-01, Resp-21 dan Resp-11 mula-mula belum memahami tentang konsep GLBB. Responden tidak mengetahui apa itu kecepatan, percepatan kecenderungan responden mengartikan kecepatan dan percepatan itu sama. Setelah dilakukan proses belajar mengajar dengan menggunakan strategi konflik kognitif berbantuan media sejarah sains Responden Resp-21 memberikan jawaban yang menarik kepada peneliti, Resp-21 tidak menjawab pertanyaan soal nomor 4 dengan benar karena mengira bahwa konsep GLBB itu tergambar pada soal nomor 3, pada sesi wawancara peneliti menemukan bahwa pada dasarnya Resp-21 mengerti konsep dari GLB dan GLBB, akan tetapi jawaban posttest yang dijumpai peneliti tidak benar, sehingga peneliti menganalisis bahwa resp-21, hanya menghafal konsep dari GLB dan 
GLBB akan tetapi Resp-21 belum mampu mengkoneksikan dan menginterpretasikan konsep itu dalam kehidupan sehari-hari.

Responden Resp-01 dan Resp-11 dan sebagian besar siswa sudah mampu menggubah prakonsepnya ke konsep yang benar.

Soal Nomor 5 mengenai konsep geraj Jatuh Bebas

Berdasarkan Tabel 4.18 sampai tabel 4.20, dapat dilihat bahwa pemahaman responden terkait soal No. 5 memberikan gambaran bahwa Responden Resp-01, Resp-21 dan Resp-11 mula-mula belum memahami tentang konsep gerak jatuh bebas, mereka mengangap bahwa benda yang massanya lebih besar akan sampai kepermukaan lebih cepat dibanding benda yang lebih ringan, pola pikir demikian ini yang tergolong berfikir Aristotelian. Setelah dilakukan proses belajar mengajar dengan menggunakan strategi konflik kognitif berbantuan media sejarah sains Responden Resp-01 memberikan jawaban yang menarik kepada peneliti. Resp-01 menjawab koin A dan B yang dijatuhkan vertikal akan jatuh secara bersamaan walapun koin A dan B memiliki massa yang berbeda, sedangkan koin $\mathrm{C}$ sampai ke lantai lebih lama dibanding koin $\mathrm{A}$ dan $\mathrm{B}$ hal ini dikarenakan lintasan koin $\mathrm{C}$ lebih besar.

Resp-21 sudah bisa menjawab dengan benar bahwa massa koin tidak mempengaruhi waktu benda jatuh kepermukaan akan tetapi Resp21 belum bisa menjawab dengan tepat kasus Koin C.

Wawancara yang dilakukan Peneliti terhadap Resp-21 menunjukkan bahwa Resp-21 pada dasarnya sudah memahami konsep gerak jatuh bebas yang mengatakan bahwa benda yang diletakkan pada ketinggian yang sama dijatuhkan bersamaan dengan massa yang berbeda akan bersamaan sampai kepermukaan jika gaya gesek diabaikan, karena waktu yang dibutuhkan benda sampai kepermukaan itu hanya dipengaruhi oleh ketinggian dan gaya grafitasi sedangkan massa tidak mempengaruhi. Cara Resp-21 menjawab koin A dan B mengunakan pola pikir Newtonian, akan tetapi pada kasus koin C Resp-21 kembali lagi ke pola berfikir Aristotelian. Resp-01 menjawab dengan benar untuk kasus koin A dan B tetapi belum bisa menginterpretasikan konsep tersebut dalam bentuk koin C.

Soal nomor 5 mengenai konsep gerak jatuh bebas, selama proses pembelajaran berlangsung menggunakan strategi konflik kognitif berbantuan media sejarah sains peneliti memberikan pertanyaan kepada siswa jika selembar kertas dan sebuah batu diletakkan pada ketinggian yang sama lalu dilepaskan secara bersamaan maka benda makan yang akan menyentuh permukaan terlebih dahulu? Sebagian besar siswa menjawab " batu". Kemudian peneliti kembali menanyakan ke siswa 
mengapa anda menjawab batu? Beberapa siswa menyampaikan prakonsepnya dalam bentuk argumen yang sebagian besar mengatakan karena baru lebih berat, sebagiannya lagi menjawab benda yang lebih ringan. Kemudian peneliti meminta salah satu siswa melakukan demonstrasi kertas yang terbentang dengan penghapus diletakkan pada ketinggian yang sama lalu dijatuhkan secara bersamaan ternyata penghapus jatuh terlebih dahulu dibanding kertas. Sebagian siswa menunjukkan ekspresi bingung hal ini menunjukkan telah terjadi proses asimilasi dan akomodasi dalam diri siswa, kemudian peneliti melanjuktkan demonstrasi kedua, peneliti meminta siswa meremaskan kertas yang terbentang tadi, kemudian diletakkan pada ketinggian yang sama dan dijatuhkan secara bersamaan, hasil demonstrasi tersebut menunjukkan bahwa kertas dan penghapus jatuhnya secara bersamaan. Peneliti kemuadian mengajukan pertanyaan ke siswa apakah massa kertas yang di bentangkan berubah ketika kertas tersebut diremukkan, sebagian siswa menjawab berubah, kemudian peneliti melakukan penguatan sehingga siswa mampu menarik kesimpulan sendiri bahwa massa tidak mempengaruhi waktu benda sampai kepermukaan seperti prakonsep yang dikonstruksi sebelumnya.

Hasil posttet menunjukkan Responden Resp-21 dan Resp-11 dan sebagian besar siswa sudah mampu menggubah prakonsepnya ke konsep yang benar setelah mendapatkan pengajaran dengan menggunakan stragei konflik kognitif berbantuan media sejarah sains .

\section{Sikap Ilmiah}

Sikap merupakan keadaan internal seseorang yang mempengaruhi pilihan-pilihan atas tindakan-tindakan pribadi yang dilakukannya. Sikap terbentuk dan berubah sejalan dengan perkembangan individu atau dengan kata lain sikap merupakan hasil belajar individu melalui interaksi sosial. Hal ini menandakan bahwa sikap dapat dibentuk dan diubah melalui pendidikan. Sikap positif dapat berubah menjadi negatif jika tidak memperoleh pembinaan yang baik. Karena sikap mempunyai tingkatan, maka sikap positif dapat juga ditingkatkan menjadi sangat positif, sehingga pada posisi seperti inilah letak peranan pendidikan dalam membina sikap seseorang. Konsep yang dibangun siswa untuk memahami lingkungannya senantiasa berubah sejalan dengan penambahan pengalaman dan bukti baru yang seringkali bertentangan dengan konsep yang sudah dipegang sebelumnya (Lestari, 2009) ${ }^{16}$

${ }^{16}$ Lestari, T. Pembelajaran Kimia dengan Inkuiri Terbimbing Melalui Metode Eksperimen dan Demonstrasi Ditinjau dari Kemampuan Awal dan Sikap Ilmiah Siswa. Tesis, Tidak diterbitkan: Universitas Sebelas Maret. 2009 
Pengukuran sikap ilmiah melalui angket sikap ilmiah dengan indikator yang diukur terdiri atas 5 aspek yaitu: sikap jujur, sikap ingin tahu, sikap kritis, sikap tekun, dan sikap dapat bekerjasama dengan orang lain serta pernyataan untuk mengukur kecerdasan sosial siswa sebagai ketambahan dari kelima aspek tersebut yang terdistribusi ke dalam 17 item pernyataan yang telah divalidasi.

Pengukuran sikap ilmiah diperoleh nilai to $>$ tabel $=4.637>2.042$ (diperoleh dari table distribusi t) dan baris Sig(1-tailed) $0.000<0.05$, dengan demikian disimpulkan bahwa $\mathrm{H}_{0}$ ditolak dan $\mathrm{H}_{1}$ diterima sehingga terdapat pengaruh yang signifikan strategi konflik kognitif berbantuan media sejarah sains terhadap Sikap Ilmiah siswa siswa pada tingkat kepercayaan $95 \%$ dan taraf nyata 0.025 .

Berdasarkan nilai tersebut dapat diasumsikan bahwa Strategi Konflik Kognitif sangat mempengaruhi tumbuhnya sikap ilmiah dalam diri setiap siswa selama proses pembelajaran. Siswa dengan sikap ilmiah yang baik akan menumbuhkan pengetahuan yang baik pula. Hal tersebut sejalan dengan teori yang dikemukakan oleh Suyitno $(1997)^{17}$ bahwa sikap ilmiah merupakan produk dari kegiatan belajar, sikap ilmiah diperoleh melalui pengalaman, pembelajaran, identifikasi, perilaku peran (guru-murid dan orang tua-anak). Karena sikap ilmiah itu dipelajari maka sikap ilmiah dapat dimodivikasi dan diubah sehingga pengalaman belajar secara konstan dapat mempengaruhi sikap ilmiah, membuat sikap ilmiah berubah, intensif, lemah ataupun sebaliknya. Hal yang serupa juga diungkapkan oleh Yul (2004) ${ }^{18}$ bahwa sikap ilmiah timbul melalui pengalaman, tidak dibawa sejak lahir, sehingga sikap dapat diperteguh atau diubah melalui proses belajar.

Nilai sikap ilmiah siswa yang diperoleh dari hasil penelitian berupa angket yang diisi siswa dan lembar observasi sikap ilmiah yang dilakukan pada saat praktikum yang dinilai salah satu guru fisika di SMA Negeri 1 Sojol sudah cukup baik dan mengalami peningkatan, namun ada beberapa siswa yang nilai sikap ilmiahnya mengalami penurunan pada saat diberi angket dan pada saat penilaian observer. Hal ini disebabkan oleh ketidakapahaman siswa tersebut dalam memberikan skor angket sikap ilmiah. Selain itu faktor lainnya adalah masih terdapat siswa yang cenderung pasif, cuek, tidak peduli terhadap pembelajaran sehingga dalam memberikan skor angket dan menjawab tes pengetahuan

${ }^{17}$ Suyitno, A. Pengukuran Skala Sikap Seseorang Terhadap Mata Pelajaran Matematika. Semarang: FMIPA IKIP Semarang. 1997.

${ }^{18}$ Yul, I. Tes, Bakat, Minat, Sikap dan Personality MMPI-DG, Jakarta: Yayasan Darma Graha. 2004. 
lingkungan mereka lakukan dengan cara menebak saja. Ketidakpedulian siswa tersebut memberikan dampak yang buruk terhadap hasil belajarnya.

Pembelajaran strategi konflik kognitif yang membangun sikap ilmiah siswa, dalam pembelajaran gerak banyak materi-materi atau konsep-konsep yang dikonstruksi oleh siswa bertentangan dengan konsep sebenarnya, sehingga pada proses pembelajaran dengan menggunakan strategi konflik kognitif berbantuan media sejarah sains melalui proses asimilasi dan akomodasi maka siswa tertantang untuk mencari dan menemukan konsep yang sebenarnya, proses untuk menemukan tersebut dilakukan dengan melakukan praktikum sehingga menumbuhkan sikap ilmiah siswa. Hal itu terlihat pada proses pembelajaran siswa lebih aktif, termotivasi belajar untuk mencari jawaban dari konflik-konflik yang dimunculkan dalam proses pembelajaran. Hal ini sejalan dengan hasil penelitian Setyowati (2011) ${ }^{19}$ menemukan bahwa strategi mengajar dengan konflik kognitif ini sangat efektif digunakan guru untuk memotivasi belajar siswa dan memfokuskan perhatian siswa pada pembelajaran, dengan demikian konflik kognitif sangat bagus untuk digunakan pada kegiatan awal pembelajaran. Strategi ini dapat membantu siswa membentuk ide baru berdasarkan pengetahuan dan pengalaman terdahulu, memberi kesempatan kepada siswa untuk berfikir dan mengubah miskonsepsi siswa, dan menantang siswa untuk berfikir dan memberikan rasa puas pada siswa ketika prediksi siswa sesuai dengan pengamatan.

\section{Kesimpulan}

Berdasarkan hasil analisis data dan pembahasan yang telah dilakukan, maka peneliti mengambil beberapa kesimpulan sebagai berikut:

1) Terdapat pengaruh yang signifikan antara Perubahan konsep siswa yang diberi pengajaran dengan strategi konflik kognitif berbantuan media sejarah sains dengan siswa yang diberi pembelajaran konvensional, hal ini bisa dilihat dengat uji t, thitung $>$ tabel (thitung 6,97 > 2,04) .

2) Terdapat pengaruh yang signifikan antara Sikap Ilmiah siswa yang diberi pengajaran dengan strategi konflik kognitif berbantuan media sejarah sains dengan siswa yang diberi pembelajaran konvensional, hal ini bisa dilihat dengat uji $t$, thitung $>t_{\text {tabel }}$ (thitung $4,64>2,04$ ).

${ }^{19}$ Setyowati, Subali, dan Mosik. Implementasi Pendekatan Konflik Kognitif dalam Pembelajaran Fisika untuk Menumbuhkan Kemampuan Berpikir Kritis Siswa SMP Kelas VIII. JPFI.7(1) 2011, 89-96. 


\section{DAFTAR PUSTAKA}

Akbar, Ilham. 2014. Pengaruh Media Sejarah Sains Terhadap Perubahan Konseptual siswa pada materi gerakan dan gaya. Tesis, tidak diterbitkan. Palu: Program Pascasarjana Universitas Tadulako.

Baser, M. 2006. "Fostering Conceptual Change by Cognitive Conflict Based Instruction on Student Understanding of Heat and Temperature Concepts". Eurasia Journal of Mathematics, Science and Technology Education. 2(2),96-114.

Fagan, M. 2012. Teaching the History of Sciences: An Experiment in the perseption of historical education. An interactive qualifying project report submitted to the faculty of Worcester Polytechnic University, Pamona

Henke, A. 2009. Case Studies for Teaching and Learning With History and Phlosophy of Sciences. Paper presented at the Tenth International History, Phylosophy, and Science Teaching Conference University of Notre Dame.

Lestari, T. 2009. Pembelajaran Kimia dengan Inkuiri Terbimbing Melalui Metode Eksperimen dan Demonstrasi Ditinjau dari Kemampuan Awal dan Sikap Ilmiah Siswa (Studi Kasus Pembelajaran Kimia pada Materi Larutan Eletrolit dan Noneletrolit Kelas X Semester 2 SMAN 1 Kebumen Tahun ajaran 2008/2009) Tesis, Tidak diterbitkan: Universitas Sebelas Maret.

Meidahrianti, Zulherman dan Taufiq. 2014. Pengaruh Strategi Pembelajaran Konflik Kognitif terhadap Perubahan Konseptual

Siswa pada Materi Gerak dinamis SMAN 1 Tanjung Batu. Jurnal inovasi pembelajaran fisika. 1(1) 48-55

Ormrod, Jeanne E. 2008. Psikologi Pendidikan Edisi ke Enam. Jakarta: Erlangga.

Setyowati, Subali, dan Mosik. 2011. Implementasi Pendekatan Konflik Kognitif dalam Pembelajaran Fisika untuk Menumbuhkan

Kemampuan Berpikir Kritis Siswa SMP Kelas VIII. JPFI.7, 8996.

Suparno, P. 1997. Filsafat Konstruktivisme dalam Pendidikan. Yogyakarta: Kanisius.

Suparno, P. 2014. Miskonsepsi dan Perubahan Konsep dalam Pendidikan Fisika. Jakarta : Grasindo

Susilawati, K., Budi, P.A., Bagus, Ida. J. 2014. Pengaruh Model Siklus Belajar 7E Terhadap Pemahaman Konsep Biologi dan Sikap Ilmiah Siswa. e-Jurnal Program Pascasarjana Universitas Pendidikan Ganesha program pendidikan IPA. Vol. 4. 
Sutisna, A. 2013. Pengembangan Model Pembelajaran Konflik Kognitif untuk Memfasilitasi Perubahan Konseptual dan Peningkatan Keterampilan Berpikir Kritis Siswa pada Materi Termokimia. Tesis Magister pada Pasca Sarjana Universitas Pendidikan Indonesia Bandung: tidak diterbitkan.

Suyitno, A. 1997. Pengukuran Skala Sikap Seseorang Terhadap Mata Pelajaran Matematika. Semarang: FMIPA IKIP Semarang.

Widiadnyana, I W., Sadia, I W., Suastra, I W. 2014. Pengaruh Discovery Learning terhadap Pemahaman Konsep dan Sokap Ilmiah Siswa SMP. e-Jurnal Program Pascasarjana Universitas Pendidikan Ganesha program pendidikan IPA. Vol. 4. 2014

Yul, I. 2004. Tes, Bakat, Minat, Sikap dan Personality MMPI-DG, Jakarta: Yayasan Darma Graha. 